\title{
THE FALL FROM THE EDENIC STATE OR THE EPOS OF AN UNFILLED LONGING
}

\author{
Fr. Prof. PhD Adrian D. COVAN, \\ Faculty of Letters, History and Theology, West University of Timișoara \\ ROMANIA \\ Email: adrian.covan@yahoo.com
}

\begin{abstract}
We learn from the texts of the Holy Scriptures and contemplations of the Holy Fathers that man was created in the image and likeness of God adorned with virtues. Resting in the Garden of Eden, the man's mind was set on contemplation of God, abounding in divine images. Dominated by the spirit, man was living in a particular state of joy and happiness. God shared him from His state of goodness, endowing him with all the spiritual and material sweetness. Man's fall into sin was a consequence of eating from the tree of knowledge of good and evil, tempted by the cunning devil disguised in primordial snake. The expel of Adam from heaven identifies with the process of humanity restoration the heavenly Father started at the gates of the biblical garden, promising to the first inhabitants of the earth to help them find the way back to their lost home, by sending in this world the Redeemer.
\end{abstract}

Keywords: The Garden of Eden; Adam; devil; sin; Saviour; return;

\section{INTRODUCTION}

Of the countless interior revelations of mankind, the one that is probably the most coveted and attempted at an inner, experimental level, is the image of the (lost) paradise. A place of plenary protection, a realm of absolute peace and an area of climatologic amenity, heaven has not ceased to be the object of the deepest ponderings and analyses. The amazing arborescence of the interpretations based upon the few first verses of the initial book of the Bible, verses that portray the splendor of the Garden of Eden in vivid colors. Those texts have become, one by one, sources of inspiration for Judaism, Christianity, and Islam.

\section{THE EDEN OF GENESIS: THE PLACE OF ORIGIN FOR OUR SPECIES}

In its first chapter, the Book of Genesis reveals things and facts that are obvious manifestations of creation, and refer to them in their generic sense; in the following two chapters, the description reveals the particularities of the human being. What becomes concrete is the fact that God made man out of the „dust of the earth" , and thus from a matter apart, which, however, is made „living being" masterpiece of God, the perfect result of His creation of and from Earth, but not of the same nature or essence as Him, but a mere projection, an image that is at a different scale, an obviously inferior one. We are dealing with a resemblance, not a consubstantiation, and this

\footnotetext{
${ }^{1}$ Genesis 2: 7.

${ }^{2}$ Ibidem.
} 
is a reflection that lives and feeds on the breath of life of its Creator alone. According to Biblical reference, this is the ontology of the human being that one must take into consideration to know the privileges, possibilities and of course, purpose of man upon Earth and in the world.

Setting aside the voluminous record of religious and other interpretations, it is enough to notice that the attractive theology of the Pentateuch gave the first garden from the earthly area a variety of symbolic schemes and images which confirm the picture of primordial good. Thus, the Garden of Eden has aesthetic, philosophical, theological and mystagogical properties ${ }^{3}$.

„The Holy Scriptures portray Heaven as a wonderful garden to the east, and this facet thus has a great importance in the Christian Church. This is why altars are always facing east, the reposed are placed facing that side of the sky, and Orthodox Christians perform their prayers turning their faces to the East. Many New Testament church saints have seen Heaven in the form of a garden. That is what it is, but its substance and nature correspond to the nature of its denizens, which are spirits; which is why Heaven is impenetrable for our senses, which have become raw on account of our profound fall"'4.

Thus, from the biblical reference about Heaven, an expose which is found in chapters 2 and 3 of the Book of Beginnings (Genesis), that Eden is the privileged place in which God put the first human couple, Adam and Eve, and from which He later cast them out, after the episode of sorrowful remembrance in which they were tempted by the Serpent Satan. The place in question was a garden in which various trees were planted, a pleasure to behold, and good for nourishment. From there sprang a river, divided into four tributaries: Pison, Gihon, Tigris and Euphrates. God puts man in the garden so that he might work it and tend to it, then fills it with all sorts of creatures made from the earth and meant to receive their names through the providential action of Adam. In the middle of this garden there stood majestically the tree of life and the tree of knowledge of good and evil ${ }^{5}$. At first sight, the place seems to be reserved exclusively to man, but it is also mentioned that God Himself was walking ${ }^{6}$ through the Garden of Eden, which reveals the fact that Paradise was, at the same time, a space of divine-human inter-habitat. At any rate, it must be understood as a place of encounter between God and man, between the Unseen and the seen. But where is this storybook realm, given that it cultivates the paradox of being at least a walking place for God and a stable place of dwelling for man? Some seek the answer in the very name of the garden. The Holy Scripture mentions the fact that God planted a garden in Eden (gan-

\footnotetext{
${ }^{3}$ See Rosario Assunto, Scrieri despre artă. Filosofia grădinii şi filosofia în grădină (Writings on Art. The Philosophy of the Garden and the Philosophy in the Garden), translated by Olga Mărculescu, Meridiane Publishing House, Bucharest, 1988, pp. 11-42.

${ }^{4}$ Father Mitrofan, Viața repausaților noștri și viața noastră după moarte (The Life of our reposed and our life after death), Credința Strămoșească Publishing House, Petru Vodă-Neamț, 2010, p. 403.

5 „I believe that Heaven reveals the heart of man planted to the east toward the knowledge of God. For in its midst did God plant the tree of life and the tree of knowledge of good and evil. The tree of life is understood as the reason of all that which is intelligible, and the tree of knowledge of good and evil as the reason of all that is sensitive, for it has the knowledge of good and evil: on one hand, for those who know the Creator from the beauty of the creatures, and through them is led to their cause[the tree] is the knowledge of good, for others, who dwell on senses alone and are deceived by the appearance of sensitive things and turn their soul with all their might [the tree] is the knowledge of evil" - Saint Maximus the Confessor, Intrebări și nedumeriri (Questions and Confusions), translated from the Greek by Laura Enache, Doxologia Publishing House, Iași, 2012 , p. 111.

${ }^{6}$ According to Genesis 3: 8. The attribution of chiefly human characteristics to God is a predisposition for the incarnation of the Son, given that the Logos of God was the person of Adamic proto-theophany.
} 
be'eden - according to Genesis 2:8). This garden was not spread throughout all of Eden, but rather a limited region. Specialists in linguistics argue in favor of the idea that the name eden is suggestive of a homophonous root, translated as „delight”. Some researchers ${ }^{7}$, however, claim that Eden is not a proper name, but a common noun derived from the Sumerian word edin, meaning plain or steppe, borrowed either directly from Sumerian or through Akkadian (edinu), and that garden was found on a plain or a flat region. Due to its placement in Eden, the garden became known as the Garden of Eden (gan'eden, according to Genesis 2: 15, and 3: 23-24 and according to Ezekiel 36:35, and Joel 2: 3), but it was also called the Garden of God (gan' Elohim, according to Ezekiel 28: 13 and 31: 9, and the Garden of the Lord (gan' YHWH - according to Isaiah 51: 3). In the Old Testament, into the book of The Song of Songs 4: 13, we find a vocabulary item taken from Persian, pardes, which, in the avestic language, meant the royal domain. We are referring to an enclosed territory known as pairidaeza. Later, the term found its way into ancient Greek, $\pi \alpha \rho \alpha \dot{\delta} \delta \varepsilon \sigma o \varsigma$, meaning „wonderful garden” or „paradise”. For example, The Septuagint uses it to describe the very Garden of Eden planted by God Himself (Genesis 2: 8 etc.). Nowadays, by „paradise” we also understand Heaven, or even the Kingdom of Heaven, imagining these as a garden of delights and of eternal partaking of the light and bliss of God. Nevertheless, the expression gan-den ${ }^{8}$ implies that this is a unitary toponym, meaning that the garden is called Eden. This is due to the fact that in the Septuagint, the Ancient Greek translation of the Hebrew original is $\pi \alpha \rho \alpha \dot{\delta} \varepsilon \imath \sigma o \varsigma \tau \eta \varsigma \tau \rho v \varphi \tilde{\eta}$, which means the garden of delights.

The verse: „And the Lord God took the man and put him into the garden of Eden to dress it and to keep it" presents the commandment that God gave the first man, once he had settled into the Garden of Heaven. One is thus motivated to wonder, in this case, what is the meaning of the commandment given unto Adam? Thus, in the book of Genesis, it is said that God planted the garden of Eden for man „to dress and keep". All of the plants were going to serve as nourishment, except for the tree in the middle of the garden, the tree of knowledge of good and evil, representing the decision reserved to God of what is right and wrong: „The day that thou eatest thereof, thou shalt surely die" (Genesis 2: 16-17). We are not given a reason for this commandment, which is not hidden, but is purely an expression of divine sovereignty over his work ${ }^{10}$. Thus, we observe that the first commandment given unto man was not referring to the aforementioned interdiction of eating from the forbidden tree, but to the commandment of working. Nevertheless, there was a veiled reference to someone who had in mind to ruin the world of God. We do not know who Adam was supposed to keep the garden from, though some interpreters of the sacred text claim it is the devil, but Adam was given a pleasant and responsible task, and it is not out of the ordinary to believe that it may refer to guarding his own work. We mention the fact that in the Hebrew language, as a direct reference to serving God and work itself, we encounter the same lexeme, avoda. The Hebrew verb shamar means to keep, to watch, to conserve, to preserve. Also, in the Aramaic Targums and the Samaritan Pentateuch, the verb $\varphi v \lambda \alpha ́ \sigma \sigma \varepsilon l v$ is used, and this verb is used to designate the activity of a master: to guard, to protect, to watch and oversee. In the Aramaic

\footnotetext{
${ }^{7}$ S. R. Driver, The Book of Genesis, Hardcover, Methuen \& Co, 1911, pp. 57-60; J. Skinner, Genesis, ICC, Edinburgh, T\&T Clark, Edinburgh, 1930, pp. 62-66.

${ }^{8}$ Genesis 3: 23-24.

${ }^{9}$ Genesis 2: 15 .

${ }^{10}$ Gabriel Bunge, Gastrimargia sau nebunia pântecelui - ştiinţa și învăţătura Părinţilor pustiei despre mâncat şi postit plecând de la scrierile avvei Evagrie Ponticul (Gastrimargy or the Madness of the Stomach - The Science and Teaching of the Fathers in the Desert on Eating and Fasting, based upon the writings of avva Evagrius of Pontus), translated by Ioan Moga, Deisis Publishing House, Sibiu, 2014, p. 56.
} 
Targums and the Samaritan Pentateuch, the word means to keep, to watch, to guard. If we analyze the entire context of the commandment, which are the following verses: „And the Lord God commanded the man, saying, Of every tree of the garden thou mayest freely eat, but of the tree of the knowledge of good and evil thou shalt not eat of it: for in the day that thou eatest thereof, thou shalt surely die!"". Then, God said: „It is not good that the man should be alone; I will make him an help meet for him" "2. We see that the commandment in Genesis 2: 15 was about, on the one hand, the physical labor of man in the Garden of Eden, about its maintenance through labor, and on the other hand, it referred to the spiritual side, to „overwatch the garden" "13; this would be the correct translation(in comparison to Numbers 3: 23, where the same word as in Genesis 2: 15 is used). Adam, the first, had the special task of overwatching the tree of the knowledge of good and evil, which could bring death into Eden, Eve, and also the fauna that he had taken into custody (Genesis 1: 28), a destiny that was unfortunately not fulfilled, and thus, through the delusion of the snake and through the delusion of Eve, death and sin penetrated the world (Genesis 3, 1-19).

"Ye shall be as gods" 14 is the age-old acerbic desire of the rebellious Morningstar. This reckless gesture led implicitly led to the disowning of Grace suffered by a part (a third, to be specific), of the angelic office, a fall that was marked upon the axis of creation with the capital letter of cosmic proportion. The frustration of this abysmal dissatisfaction brought an outburst articulated through hatred, manifested upon the entirety of creation, namely, man, made and set by God in the world as a ruler over being. This is a property that was given as a gift, not one that existed through the nature of man, for man is not meant to be Creator, but keeper or administrator of all that is seen. However, the founder of evil, exiled upon earth, sought to banish man from the Land of Bliss - the Garden of Eden - forevermore, seducing him with the pseudo-aspiration of self-godliness ${ }^{15}$. Eden had become the habitat of man, but

11 Genesis 2: 17. „The word and idea of death first struck upon the hearing and the mind of man when he entered heaven. Among all of the trees of the garden, two were most remarkable: The Tree of Life and the tree of the knowledge of Good and Evil. Putting man into Heaven, God commanded him: Of every tree of the garden thou mayest freely eat, but of the tree of the knowledge of good and evil thou shalt not eat of it: for in the day that thou eatest thereof, thou shalt surely die! In spite of the frightening death threat, man broke the commandment and immediately died; death was apparent without delay in all the movements of the soul and in all the feelings of the body. The Holy Ghost, which dwelled within man, which shared immortality with the body and the soul, which was their life, separated from man and woman as from those who had broken communion with God through a wicked union in thought and in companionship with Satan" - Saint Ignatius Brianchaninov, Cuvânt despre moarte (A word on death), translated by Adrian and Xenia Tănăsescu-Vlas, Sofia Publishing House, Bucharest, 2007, p. 72.

${ }^{12}$ Genesis 2: 18.

${ }^{13}$ Reminding that some of his predecessors are inclined to consider Paradise spiritually and others sensually, Saint John of Damascus mentioned: „,...but to me, it seems as though, as man was created as corporeal and spiritual and the same time, the same can be said about his hallowed dwelling place, having been created as corporeal and spiritual at the same time, having a double appearance" - See Dogmatica (Dogmatics), translated by Dumitru Fecioru, Scripta Publishing House, Bucharest, 1993, p. 57.

${ }^{14}$ Genesis 3: 5.

15 „This childlike dialogue and the ease with which our forefathers fell into breaking the one commandment given unto them reveals the untried nature of their being: all had been given unto them by the Grace of God, but they knew not yet how to „dress and keep” their innermost nature. The temptation put before them by the devil contains the same things that we, as fallen human beings, know from the struggle against sin. First and foremost, he does not use a thing that is visibly evil, but something that seems good and true. Human beings were indeed meant to be as gods and sons of the Most High (Psalm 81: 6), knowing that from Heaven they would move to a higher state. But the Devil seems to have said (as Saint Ambrose reveals): Behold, therefore, my first attempt at deluding him when he is overcome with the yearning for improving his state. Thus, we will seek to stir his hunger for greatness" - Seraphim Rose, Cartea Facerii, crearea lumii noi și întâiul om: 
it also represented, at the same time, the paradise lost of the dark Cherub. We all know that which came afterwards: through his autonomy, man contributed to social atomization which is reflected in the convulsion of the division of humanity, which means the dismantling of the principle of personal unity to the unfortunate individualism of an autocratic and an autarchic anthropocracy. Thus, from a satellite of the Living God, man, under the influence of the sign of sin, becomes a planet tilted towards the orbit of the fallen star - the enemy of God and all creation. The demonization of the human is achieved through the demonetization of the face of God within man, which undoubtedly leads to the impossibility of ascending his theophoric face to the power of resemblance to the All-Holy-One. The annulment of the spiritual constitution consists of the dismissal of spiritual faculties: reason, will, and feeling, from under the tutelage of the culture of the Holy Ghost - the absence of the Holy Ghost from the life of man coincides with the renunciation of acquiring the thought(mind) of Christ. The anguish of post-paradise life can be found encrypted in the exclamation of the prodigal son, whose misfortunate life took place under the Spartan conditions of the lack of the presence of God. The thematic of inner peace can only be understood via repentance as a state of spiritual regeneration. The Sinai law and the Gospel of Life are the coordinates for cleansing and spiritual healing applied by God to man, who is under the vice of sin. The nostalgia ${ }^{16}$ of the paradise lost will follow Adam - the Prodigal Son - for all his life, even going with him to Sheol.

\section{THE GATES OF HEAVEN ARE OPEN - THE DIVINE ORIGIN OF SALVATION AS THE HEALING OF THE FALLEN HUMAN}

Man - the icon of God - was meant to become godly through perfect communion with his Creator. The intention was good, for it was inscribed in human nature itself (the tendency towards godliness), but the procedure through which Adam attempted to become godly was an atheosic procedure. Saint Maximus the Confessor was mentioning the fact that the mistake man commits it not that of wanting to become like God, for that was his destination. The error is represented by his desire to become like God by knowing good and evil and suppressing theandric synergy ${ }^{17}$. The nutrition that man needed in order to grow in communion with God was the Tree of Life, so God Himself.

In becoming flesh, the Son of God exposes to the entire world the harmony of the two lit fires: the longing of God for man and the longing of man for God, intersected in the tangible reality of two of the paradoxical episodes that compose the feature-length picture of the economy of salvation of the world through Christ: The Cross upon which the Man-God died and the empty tomb. Eternity and Time are mutually harmonizing in a complete hypostatic intertwining in the earthly vestments of the Godly Logos found in a state of descent-kenosis. The rediscovery of the primordial experience of the relationship of man and God is quantified from seeing God. This is derived from the prosoponic - meaning face-to-

perspectiva creștin-ortodoxă (Genesis, Creation and Early Man: The Orthodox Christian Vision), translated from English by Constantin Făgețan, Second edition, revised, Sophia Publishing House, Bucharest, 2011, p. 127.

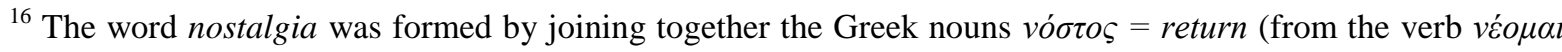
$=$ to return, to go back) and $\ddot{\alpha} \lambda \gamma o \varsigma=$ pain (physical or spiritual).

${ }^{17}$ Panayotis Nellas, Omul animal îndumnezeit (Man, the godly animal), translated by Ioan I. Ică jr., Deisis Publishing House, Sibiu, 2009, p. 87. See, also, Alin Cristian Scridon, Georgije Zubković, a noble soul of the Romanian Orthodox in interwar Hungary. A Romanian record under the scrutiny of historiography and diplomatic and ecclesiastical documents, in Bogoslovlje, Journal of the Faculty of Orthodox Theology, University of Belgrad, no. 2/2020, p. 93. 
face - encounter between man and God, but also the acquisition of the manner of seeing God

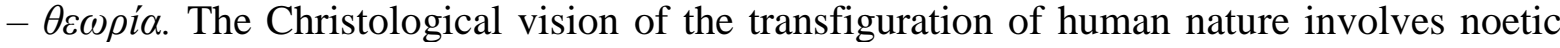
clarity. By easily crossing the intermediate corridors between the mind and Word, through the exposure of the nature of the Adamic man to the radiations of the holiness of God, the Lord Jesus revealed, through His life as shown in the Gospels, the antithesis between the Tree of Life and the brambles of $\sin ^{18}$. Man has privatized creation, annexing it to the self, to the spiritualizing Breath - the unintermediated presence of the Holy Ghost, which came about via the redeeming direction of Christ.

A question lingered upon the lips of everyone, Fathers of the Church and heretics alike: How was it possible for one from the Holy Trinity, born of Eternity, from the Father without beginning, to submit Himself to the biological process of birth. The economic vision of salvation of the world in Christ, which begins with the birth of the Word of God by flesh, is now introduced to the world. The Trinitarian paradox: The Born is One with the Unborn is contrasted to the image of the Christological paradox: man and God at the same time. The Fathers of the Golden Age, alias the fourth century, shall be the pioneers of this accomplishment of the Church, referring directly to the theme of Incarnation as being closely related to our salvation, salvation, in effect, meaning the reunion of human nature with the Father, by Grace. The following Christological scheme: The Word becoming Man, Man becoming Godly, belonging to Saint Athanasius the Great, the Archbishop of Alexandria, Egypt, is all the more eloquent since consubstantiality or the Oneness in being between the Father and The Son itself involves full salvation, not an imaginary redemption arc. Saint Gregory the Theologian, a craftsman of Christological sermons, and more, revealed that though God has no particular cause, nevertheless „He was born for a cause. And this was: so that you, who offend Him, who despise Divinity, for having received your raw self. For by union with the body by the mediation of the mind, God became lowly man, for he merged with God and became One, the superior becoming victorious, so that I may become as much God as He became $\operatorname{man}^{19}$.

But how was the union between the Divine and the human possible through Incarnation in the Person of the Son. The same Holy Father clarifies the problem in a special manner: „The Word of God, before all ages, the unseen, the one which cannot be encompassed by the mind, the immaterial, the beginning of the beginning, the source of life and immortality, the expression of the beauty of the original visage, the immovable seal, the unchanged face, the border and the Word of the Father, comes unto His own face and mixes with the pondering soul on account of my soul, that through its peer, it might cleanse it from sin. And He becomes man in all but sin, conceived of a virgin purified beforehand by the Spirit in body and soul... God in human nature taken upon Himself, walking through the

18 „The Lord, in the Garden of Gethsemane, wept because He knew that not many would benefit from His suffering on the cross, but many, through ill-will, stray from salvation. If someone hopes to get to the point where the Holy Trinity is, let them strive not to lose sight of Christ Incarnate. Those who reach the point of freedom from their vices will be where the Holy Trinity is, and those who gain forgiveness of sins become worthy of living within the Garden of Heaven, and contemplate the Face of Christ" - Saint Ambrose of Optina, Patericul de la Optina (The Patericon of Optina), translated by Florentina Cristea, Egumenița Publishing House, Galați, 2012, pp. 256-257.

${ }^{19}$ Saint Gregory of Nazianzus, Cele cinci cuvântări teologice (The five theological speeches), III, 19, translated by Dumitru Stăniloae, Anastasia Publishing House, Bucharest, 1993, p. 67. 
world, one of two contrary natures, Flesh and Spirit, one rendering Godly, one becoming Godly. Oh, what an awesome union, what a wonderful combination!"20.

The dogmas of the Church influence one another, transforming Christian thought into a monument of the excellence of Truth. If triadology leads implicitly to Christology, the latter amplifies its meaning through anthropology, but in an eminently soteriological perspective. The passage from the peristasis of $\Lambda o ́ \gamma o \varsigma \dot{\varepsilon} v \delta l \dot{\alpha} \theta \varepsilon \tau o \varsigma$ (finder in God) to that of

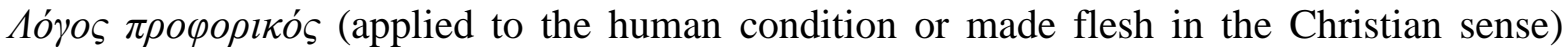
expresses the principle of the wonderful exchange ${ }^{21}$. Thus, the Word became Man so that we may be made God, not by being, but by flesh. The Son of God took a visible body, so that we might know God-the Father, the invisible. And again ,The Word became flesh, and the Son of God became Son of Man, for man, joining with the Word, thus receiving adoptive filiation, becoming a son of God"22.

\section{CONCLUSION}

To conclude with, through and in Christ, the fulfilment of time ${ }^{23}$ becomes the debut moment of the neo-Adamic existence. Eden, our ,ancestral and parental homeland, had remained closed for all, since the estrangement of Adam. Jesus reopens it now, in the presence of the thief, who is the first among those who entered the Kingdom of Heaven" ${ }^{24}$. Thus, the Holy Doors of Heaven are open, and the night of estrangement from God, as well as the darkness of man being locked in the shell of his own self, are abolished forever. This is the reason for which, as Father Dumitru Stăniloae said, ,the Lord was made flesh, crucified, and resurrected as man, so as to gather all those divided in Himself, in the infinity of His love for the Father, and of the love of the Father for Him"25.

\section{BIBLIOGRAPHY:}

[1] Biblia sau Sfânta Scriptură (The Bible or Holy Scripture), IBMBOR Publishing House, Bucharest, 1968.

[2] Saint Ambrose of Optina, Patericul de la Optina (The Patericon of Optina), translated by Florentina Cristea, Egumenița Publishing House, Galați, 2012.

[3] Blessed Augustine, Sermo, in Jaques-Paul Migne, Patrologia Latina, vol. 39, Bibliothecae Cleri Universae, Paris, 1865.

[4] Saint Gregory of Nazianzus, Cele cinci cuvântări teologice (The five theological speeches), translated by Dumitru Stăniloae, Anastasia Publishing House, Bucharest, 1993.

[5] Saint Gregory of Nazianzus, Cuvântare la Sfintele Paşti (Speech for Holy Easter) in Opere dogmatice (Dogmatic works), translation, studies and notes by Gheorghe Tilea, Herald Publishing House, Bucharest, 2002.

[6] Saint Ignatius Brianchaninov, Cuvânt despre moarte (A word on death), translated by Adrian and Xenia Tănăsescu-Vlas, Sofia Publishing House, Bucharest, 2007.

\footnotetext{
20 Idem, Cuvântare la Sfintele Paşti (Speech for Holy Easter) in Opere dogmatice (Dogmatic works), translation, studies and notes by Gheorghe Tilea, Herald Publishing House, Bucharest, 2002, p. 69.

${ }^{21}$ Bernard Sesboue, Hristologia patristică: repere principale (Patristic Christology: main references), in Sfinţii Părinţi pe inţelesul tuturor (Holy Fathers for Everyone collection), Anastasia Publishing House, Bucharest, 2004, p. 29.

${ }^{22}$ Saint Ireneus of Lyon, Contre les hérésies (Against Heresies), III, 19, 1, in Sources Chrétiennes, Les Edition Du Cerf, Paris, 1974, p. 368.

${ }^{23}$ Galatians 6, 4.

${ }^{24}$ Blessed Augustine, Sermo 104, in Jaques-Paul Migne, Patrologia Latina (abreviat PL), vol. 39, Bibliothecae Cleri Universae, Paris, 1865, 2045.

${ }^{25}$ Dumitru Stăniloae, Teologia Dogmatică Ortodoxă (The Orthodox Dogmatic Theology), vol. 2, IBMBOR Publishing House, Bucharest, 1997, p. 263.
} 
[7] Saint Ireneus of Lyon, Contre les hérésies (Against Heresies), in Sources Chrétiennes, Les Edition Du Cerf, Paris, 1974.

[8] Saint Maximus the Confessor, Întrebări și nedumeriri (Questions and Confusions), translated from the Greek by Laura Enache, Doxologia Publishing House, Iași, 2012.

[9] Saint John of Damascus, Dogmatica (Dogmatics), translated by Dumitru Fecioru, Scripta Publishing House, Bucharest, 1993.

[10] Assunto, Rosario, Scrieri despre artă. Filosofia grădinii și filosofia în grădină (Writings on Art. The Philosophy of the Garden and the Philosophy in the Garden), translated by Olga Mărculescu, Meridiane Publishing House, Bucharest, 1988.

[11] Bunge, Gabriel, Gastrimargia sau nebunia pântecelui - ştiinţa și învătătura Părinţilor pustiei despre mâncat şi postit plecând de la scrierile avvei Evagrie Ponticul (Gastrimargy or the Madness of the Stomach - The Science and Teaching of the Fathers in the Desert on Eating and Fasting, based upon the writings of avva Evagrius of Pontus), translated by Ioan Moga, Deisis Publishing House, Sibiu, 2014.

[12] Driver, S. R., The Book of Genesis, Hardcover, Methuen \& Co, 1911.

[13] Mitrofan, Father, Viața repausaților noștri și viața noastră după moarte (The Life of our reposed and our life after death), Credința Strămoșească Publishing House, Petru Vodă-Neamț, 2010.

[14] Nellas, Panayotis, Omul animal îndumnezeit (Man, the godly animal), translated by Ioan I. Ică jr., Deisis Publishing House, Sibiu, 2009.

[15] Rose, Seraphim, Cartea Facerii, crearea lumii noi și intâiul om: perspectiva creștinortodoxă (Genesis, Creation and Early Man: The Orthodox Christian Vision), translated from English by Constantin Făgețan, Second edition, revised, Sophia Publishing House, Bucharest, 2011.

[16] Scridon, Alin Cristian, Georgije Zubković, a noble soul of the Romanian Orthodox in interwar Hungary. A Romanian record under the scrutiny of historiography and diplomatic and ecclesiastical documents, in Bogoslovlje, Journal of the Faculty of Orthodox Theology, University of Belgrad, no. 2/2020.

[17] Sesboue, Bernard, Hristologia patristică: repere principale (Patristic Christology: main references), in Sfinţii Părinţi pe inţelesul tuturor (Holy Fathers for Everyone collection), Anastasia Publishing House, Bucharest, 2004.

[18] Skinner, J., Genesis, ICC, Edinburgh, T\&T Clark, Edinburgh, 1930.

[19] Stăniloae, Dumitru, Teologia Dogmatică Ortodoxă (The Orthodox Dogmatic Theology), vol. 2, IBMBOR Publishing House, Bucharest, 1997. 